\title{
Oxidative stress in chronic periodontitis patients with type II diabetes mellitus
}

\author{
Ruby Ramya Vincent ${ }^{1}$, Devapriya Appukuttan ${ }^{1}$, Dhayanand John Victor ${ }^{1}$, \\ Aruna Balasundaram ${ }^{1}$
}

Correspondence: Dr. Ruby Ramya Vincent

Email: rubyramyavincent@gmail.com
'Department of Periodontics, SRM Dental College and Hospital, Chennai, Tamil Nadu, India

\section{ABSTRACT}

Objective: Oxidative stress (OS) refers to the disequilibrium between free radicals and antioxidant defense mechanisms and is significantly implicated in the pathogenesis of chronic degenerative and inflammatory diseases such as chronic periodontal disease (CP) and diabetes mellitus (DM). This study aimed to evaluate the total antioxidants capacity (TAOC) and total oxidants status (TOS) in the gingival crevicular fluid (GCF) in CP participants with type II DM. Materials and Methods: A total of 80 participants were allotted into four groups as follows: Group 1: Generalized CP (GCP) without type II DM $(n=20)$; Group 2: GCP with type II DM $(n=20)$; Group 3: Type II DM without CP $(n=20)$; and Group 4: Systemically and periodontally healthy $(\mathrm{PH})(n=20)$. Clinical parameters such as plaque index, gingival index, probing pocket depth, and clinical attachment level were recorded. Pooled GCF was collected followed by the estimation of TAOC, TOS, and OS index (OSI) using Erel O Colorimetric analysis. Results: The clinical parameters recorded showed the statistically significant difference $(P<0.001)$ between the groups. The mean TAOC value was the highest in PH group. The mean TOS and OSI were higher in Group 1,2, and 3 participants when compared to the $\mathrm{PH}$ participants. All the biochemical parameters evaluated showed a statistically significant difference $(P<0.001)$ between groups. Conclusions: The study further validates the use of OSI as a marker for periodontal disease activity and emphasizes the role of OS in the pathogenesis of Type II diabetic patients with the chronic periodontal disease.

Key words: Chronic periodontitis, oxidative stress, total antioxidant capacity, total oxidant status, type II diabetes mellitus

\section{INTRODUCTION}

Periodontal diseases are complex chronic inflammatory diseases that destroy the supporting tissues of the periodontium and are highly prevalent among the general population. ${ }^{[1]}$ The current proposition for the pathogenesis of periodontal disease emphasizes on "microbial dysbiosis" wherein a shift in the symbiotic beneficial microbial communities in the plaque biofilm to pathogenic bacteria primarily accounts for the initiation of periodontal disease. ${ }^{[2]}$ Nonetheless, it is the host responses against these microorganisms

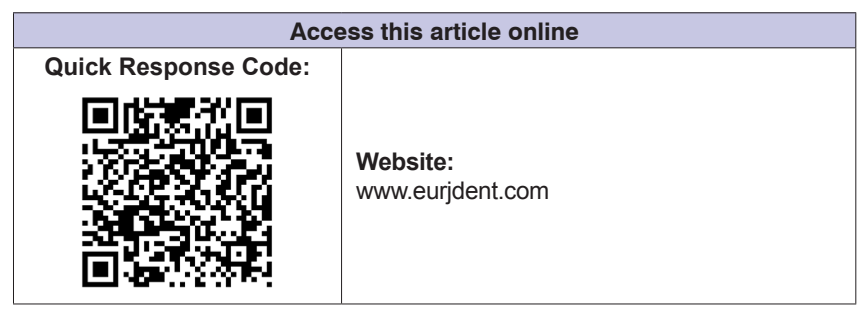

that play a crucial role in determining the course and severity of the disease. ${ }^{[3]}$

Proinflammatory cytokines secreted as a part of protective immune responses facilitate recruitment of polymorphonuclear leukocytes to the site of infection. These cells release proteolytic enzymes and reactive oxygen species (ROS) through the oxidative burst, catalyzed by nicotinamide adenine dinucleotide phosphate hydrogenase (NADPH)

This is an open access journal, and articles are distributed under the terms of the Creative Commons Attribution-NonCommercial-ShareAlike 4.0 License, which allows others to remix, tweak, and build upon the work non-commercially, as long as appropriate credit is given and the new creations are licensed under the identical terms.

For reprints contact: reprints@medknow.com

How to cite this article: Vincent RR, Appukuttan D, Victor DJ, Balasundaram A. Oxidative stress in chronic periodontitis patients with type II diabetes mellitus. Eur J Dent 2018;12:225-31.

DOI: 10.4103/ejd.ejd_244_17 
oxidase. ${ }^{[4]}$ The released free radicals enter the extracellular environment as they are not target-specific and during their course of action there is reciprocal damage to the host tissues, and this can come about either by direct oxidation of the vital tissue components or indirectly by activation of transcription factors. Thus, the immuno-inflammatory defensive mechanisms intended to protect the host tissues can be injurious to periodontal tissues and are consequently involved in the pathogenesis of periodontal disease. ${ }^{[5]}$

Diabetes mellitus (DM) like periodontitis is a chronic inflammatory disease characterized by hyperglycemia that induces an exaggerated proinflammatory state, oxidative stress (OS), and apoptosis. ${ }^{[6]}$ There is altered immune cell functions coupled with defective neutrophil apoptosis, systemically hyper-responsive monocytes and macrophages in diabetics with the resultant excessive production of inflammatory mediators such as interleukin-1 $\beta$ (IL-1 $\beta$ ), tumor necrosis factor- $\alpha$, and ROS in response to bacterial antigens. ${ }^{[7]}$ Furthermore, the advanced glycation end products (AGEs) that accumulate within periodontal tissues appreciably alter normal cellular composition and structure. They increase cross-linking of collagen proteins and enhance respiratory burst in neutrophils, thereby disrupting the normal barrier function and integrity of the tissues. Therefore, the outcome of this exaggerated inflammatory response in diabetics is the inefficient elimination of pathogenic bacteria in the periodontal pocket, resulting in continued periodontal tissue destruction. ${ }^{[8-15]}$

Both these diseases are coupled with hyper-inflammation and increased OS and literature evidence indicates a bi-directional interrelationship between DM and periodontitis wherein, diabetes increases the risk of periodontitis and periodontitis could have a negative effect on the glycemic control in susceptible individuals. ${ }^{[6,7]}$ OS is defined as "an imbalance between oxidants and antioxidants in favor of the oxidants, potentially leading to damage." [9] This consequently leads to inflammation, either acute or chronic, depending on how long the imbalance continues in favor of the oxidants compared to antioxidants. Antioxidants are molecular compounds present at lower concentrations and are protective against oxidants by significantly delaying or inhibiting the oxidation of substrates that are present at higher concentrations. $^{[10,11]}$

Currently, no gold standard investigations are available for measuring the antioxidant capacity or
ROS mediated tissue damage. However, indirectly OS can be determined by estimating the total antioxidant capacity (TAOC), or by estimating the products of oxidative damage to lipids, proteins, and DNA. A multitude of oxidants are present in a biologic system and individual assessment of these molecules is not practical; moreover, their oxidant effects are additive; hence, evaluating the total oxidant status (TOS) is more pertinent. Similarly, estimating TAOC reduces the cost and time necessary to measure individual antioxidant species besides, it may also account for the antioxidants that are yet undiscovered or are technically difficult to assay. ${ }^{[12]}$ Hence, both TOS and TAOC serve as logical approaches to the assessment of OS. In the recent times, a novel parameter, the OS index (OSI), has been developed which more clearly defines the oxidant/ antioxidant imbalances in chronic inflammatory diseases such as diabetes and periodontitis. ${ }^{[12,13]}$

To the best of our knowledge, there are no previously published studies estimating gingival crevicular fluid (GCF) TAOC, TOS and OSI in Generalized Chronic Periodontitis patients (GCP) with Type II DM. The study primarily aimed at estimating the levels of GCF TAOC, TOS, and OSI in GCP patients with and without Type II DM. Secondarily, to compare and correlate these biochemical markers of OS with the clinical parameters of Periodontal Disease.

\section{MATERIALS AND METHODS}

This case-control study was conducted in the Department of Periodontics, SRM Dental College, Ramapuram, Chennai. The study period was from January 2016 to April 2016. The research proposal was placed before the Institutional Scientific and Ethical Review Board and approval was obtained before the commencement of the study (SRMDC/IRB/2014/ MDS/No. 505).

A total of 80 participants were recruited based on the inclusion criteria laid down for the study following which they were allotted into four study groups as follows: Group 1: GCP patients without type II DM (20 participants); Group 2: GCP patients with type II DM (20 participants ) (GCP-DM); Group 3: Patients with type II DM without CP (20 participants) (DM); Group 4: Systemically and periodontally healthy $(\mathrm{PH})$ individuals (20 participants ). The protocols followed in the study are given in the flow chart [Figure 1].

The participants were diagnosed with GCP based on the American Academy of Periodontology criteria 


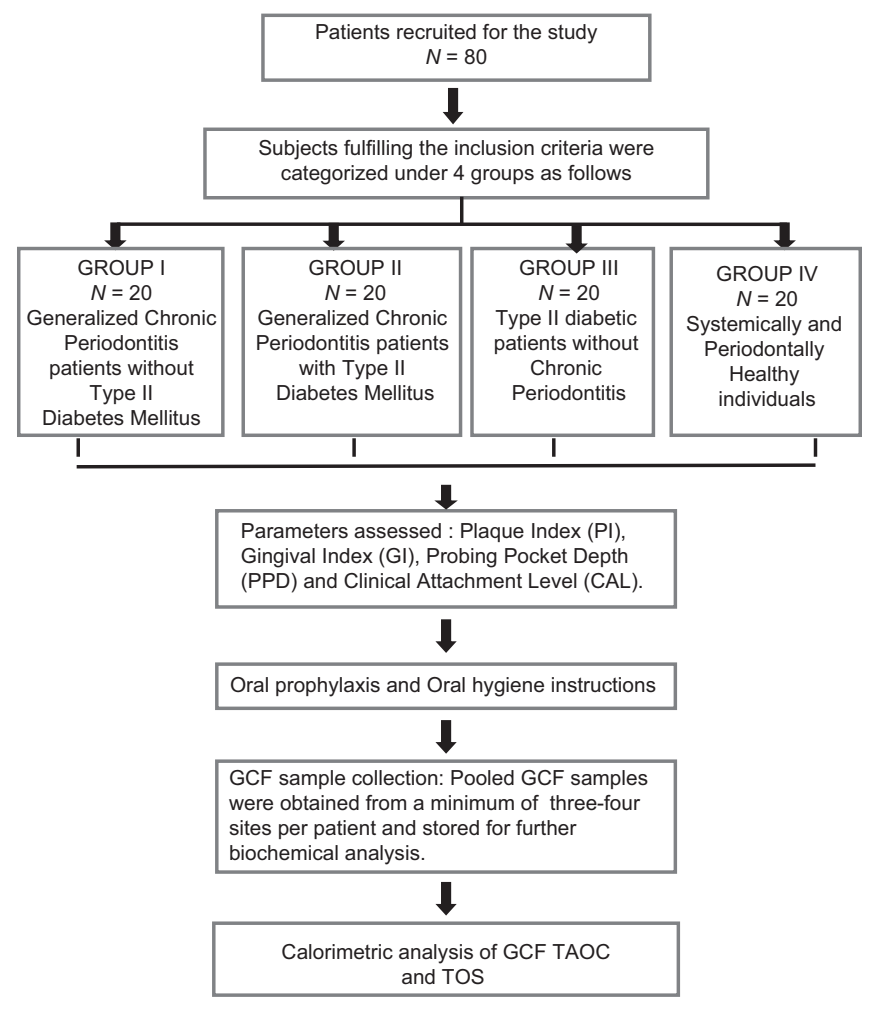

Figure 1: Schematic representation of the study design

given in 1999. ${ }^{[16]}$ They were required to have a minimum of 20 teeth present with at least 5 teeth in each quadrant, with a probing pocket depth (PPD) of $\geq 5 \mathrm{~mm}$ with clinical attachment loss of $\geq 1 \mathrm{~mm}$ in more than $30 \%$ of sites with mild to moderate periodontitis, and presence of $>30 \%$ of sites with bleeding on probing. Those patients aged between 25 and 65 years willing to participate and accepted to give informed consent were recruited.

Participants diagnosed with type II DM by a diabetologist and under treatment with oral hypoglycemic drugs and diet control for a minimum of 6 months were included in the Group 2 and 3. ${ }^{[17]}$ These participants were requested to bring their latest, i.e., within 3 months blood glucose reports (preferably fasting and postprandial or glycated hemoglobin) during the subsequent visits, however, if the report was not available the above investigations were requested. Participants with any other systemic diseases or conditions other than type II DM that could influence the course of periodontal disease and diabetics with a previous history of diabetic complications were excluded from the study. In addition, smokers or any other forms of tobacco consumers, alcohol drinkers, those giving a history of antibiotic or anti-inflammatory intake or regular intake of vitamins, mineral or antioxidant supplements or regular mouthwash users within the preceding 3 months and pregnant/lactating women were requested not to participate in the study.

\section{Periodontal examination}

The periodontal parameters assessed were the Silness and Loe plaque index (PI), Loe and Silness gingival index (GI), PPD and the clinical attachment level (CAL) with relation to the teeth present. Plaque and gingival scores were evaluated on all teeth, four sites per tooth (mesio-buccal; mid-buccal; disto-buccal and palatal/lingual). The PPD and CAL were recorded for all teeth, 6 sites per tooth (mesio-buccal, mid-buccal, disto-buccal, disto-palatal/lingual, mid-palatal/ lingual, mesio-palatal/lingual) respectively using a University of North Carolina- 15 periodontal probe.

\section{Collection of gingival crevicular fluid}

After the clinical parameters were recorded, complete supra-gingival ultrasonic scaling was completed followed by collection of GCF samples between 24 and $48 \mathrm{~h}$ after scaling, to ensure that the effect of mechanical irritation on the GCF levels was avoided. The participants were made to sit comfortably in an upright position and the sites to be sampled were isolated with cotton rolls. The sites with the deepest PPDs were selected for sampling in Groups 1 and 2. Approximately 15-20 $\mu$ l of GCF was collected from each patient by pooling samples from 3 to 4 sites ensuring that at least one deepest site per quadrant was sampled. GCF was collected from healthy sites with no clinical inflammation (PPD $\leq 3 \mathrm{~mm}$ and $\mathrm{GI}=0$ ) in Groups 3 and 4 . Those samples contaminated with blood were discarded. GCF was collected by placing the micro-capillary pipettes ( $5 \mu \mathrm{l}$ micro-capillary pipettes, Sigma Aldrich, St Louis, MO, USA) at the entrance of the gingival sulcus, and allowing the pipettes to gently penetrate into the gingival crevice. The GCF collected were pooled into Eppendorf tubes, containing $200 \mu \mathrm{l}$ of $20 \mathrm{mM}$ Tris- $\mathrm{HCl}$ buffer (PH 6.5) and they were stored at $-80^{\circ} \mathrm{C}$, until analysis.

\section{Biochemical assay}

The total antioxidant and oxidant status assay kits (Rel Assay Diagnostics, Turkey) were procured, and the TAOC and TOS of GCF were measured using the Erel O's novel automated method of Colorimetric analysis. The percentage ratio of TOS to TAOC was accepted as OSI. ${ }^{[18,19]}$

\section{Statistical analysis}

All statistical analysis was performed using Statistical Package for Social Science (IBM SPSS Statistics for Windows, Version 20.0. Armonk, NY: IBM Corp) 
for Microsoft windows. The data were normally distributed and therefore, parametric tests were applied. To compare the mean values between groups, one-way analysis of variance was applied followed by Tukey's post hoc test for multiple pairwise comparisons. The correlations between the clinical and the biochemical parameters were analyzed using Pearson's correlation test. A value of $P<0.05$ was considered to be statistically significant.

\section{RESULTS}

The study population included 80 adult patients (34 females and 46 males) with a mean age of 40.6 years (ranging from 25 to 65 years), recruited from the outpatient clinic based on the inclusion and exclusion criteria. The mean age \pm standard deviation of participants in Group 1, 2, 3, and 4 were $38.10 \pm 8.41$ years, $48.85 \pm 8.89$ years, $47.10 \pm 8.85$ years, and $28.60 \pm 4.10$ years, respectively. Gender-wise distribution revealed that in Group 1, 10 men and 10 women were present, in Group 2 and Group 4 similar distribution was seen with 11 men and 9 women in each group, respectively, 14 men and 6 women were present in Group 3.

Based on the selection criteria and grouping of the study subjects, it was apparent that the clinical parameters of gingival inflammation and plaque scores were higher in participants with GCP, GCP-DM, and DM when compared with the PH. Similarly, the parameters for destructive periodontal disease such as PPD and CAL were higher in GCP and GCP-DM group when compared with DM and PH group. All the clinical parameters evaluated showed a statistically significant difference $(P<0.001)$ between the groups [Tables 1 and 2]. The mean TAOC values were higher in PH group than in Group 1, 2, and 3. The mean TOS and OSI were higher in Group 1, 2 and 3 participants when compared to the $\mathrm{PH}$ subjects. All the parameters showed a statistically significant difference $(P<0.001)$ between groups [Tables 3 and 4]. The GI and TAOC were negatively correlated, and PPD and the OSI were positively correlated in Group $1(P<0.05)$ [Figures 2 and 3].

\section{DISCUSSION}

Inflammation and OS are associated with a number of chronic diseases such as DM, atherosclerosis hypertension, myocardial infarction, cerbro-vascular stroke, chronic kidney disease, cancer, as well as periodontal disease. ${ }^{[20,21]}$ Inflammation is a protective

\begin{tabular}{|c|c|c|c|c|c|}
\hline \multirow[t]{2}{*}{ Parameters } & \multicolumn{4}{|c|}{ Mean $\pm S D$} & \multirow[t]{2}{*}{$P$} \\
\hline & $\begin{array}{l}\text { Group } 1 \\
\text { (GCP) }\end{array}$ & $\begin{array}{c}\text { Group } 2 \\
\text { (GCP-DM) }\end{array}$ & $\begin{array}{c}\text { Group } 3 \\
\text { (DM) }\end{array}$ & $\begin{array}{c}\text { Group } 4 \\
\text { (PH) }\end{array}$ & \\
\hline $\mathrm{PI}$ & $1.28 \pm 0.45$ & $1.49 \pm 0.26$ & $1.51 \pm 0.43$ & $0.36 \pm 0.16$ & $0.001^{* \star}$ \\
\hline GI & $1.37 \pm 0.42$ & $1.62 \pm 0.24$ & $1.25 \pm 0.38$ & 0.000 & $0.001^{\text {** }}$ \\
\hline PPD (mm) & $5.28 \pm 0.22$ & $5.42 \pm 0.23$ & $2.30 \pm 0.31$ & $1.51 \pm 0.22$ & $0.001^{* *}$ \\
\hline $\mathrm{CAL}(\mathrm{mm})$ & $2.51 \pm 0.38$ & $2.87 \pm 0.72$ & 0.000 & 0.000 & $0.001^{\text {** }}$ \\
\hline \multicolumn{6}{|c|}{$\begin{array}{l}{ }^{* *} P<0.01 \text {, highly significant. CAL: Clinical attachment level, } \\
\text { PPD: Probing pocket depth, GI: Gingival index, Pl: Plaque index, } \\
\text { GCP: Generalized chronic periodontitis, GCP-DM: Generalized } \\
\text { chronic periodontitis with DM, DM: Type II diabetes mellitus, } \\
\text { PH: Periodontally healthy, SD: Standard deviation }\end{array}$} \\
\hline
\end{tabular}

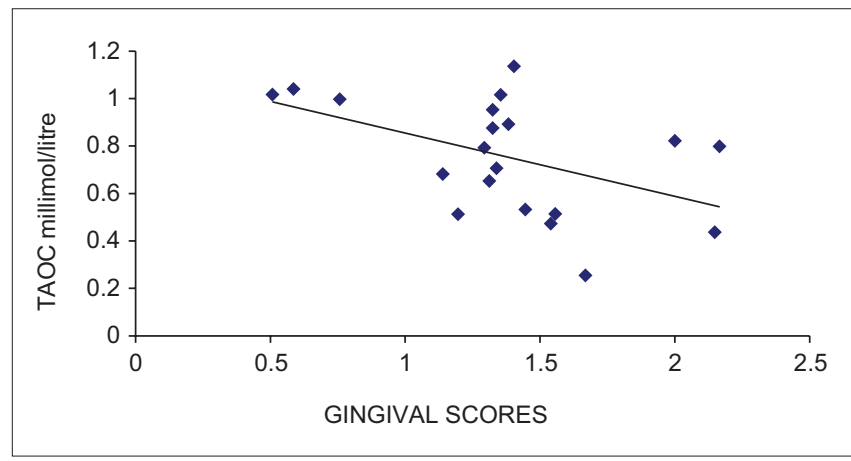

Figure 2: Correlation between gingival index and total antioxidant capacity in Group 1 (chronic periodontitis without diabetes mellitus)

response of vascular tissue to injurious stimuli, and the process aims to restore the balance by eliminating pathogens and noxious stimuli. However, prolonged dysregulated inflammation can lead to tissue destruction via OS wherein there is an imbalance between oxidants and anti-oxidants due to either an increase in free radical production and activity or due to a reduced antioxidant defense mechanism. ${ }^{[4,5]}$ OS is a common factor in both periodontal disease and DM through a hyperactive innate immunity and an upregulated host immune-inflammatory response. The coexistence of these two diseases in the host can have synergistic effects with greater imbalance in redox control. ${ }^{[10,11]}$

GCF is an inflammatory exudate and may serve as a site-specific marker to assess current periodontal status. It can also be utilized as a plasma exudate that is an indicator of systemic health or disease, thereby useful as an indicator of systemic conditioning of the periodontium. It can be conveniently collected by noninvasive methods and can be stored up until analysis. ${ }^{[12,22]}$ Hence, crevicular fluid samples were collected for estimation of the biochemical markers in this study. Moreover, no studies until date have analyzed crevicular fluid levels of TAOC, TOS 


\begin{tabular}{|c|c|c|c|}
\hline $\begin{array}{l}\text { Clinical } \\
\text { parameters at } \\
\text { baseline }\end{array}$ & $\begin{array}{l}\text { Pairwise comparison } \\
\text { between groups }\end{array}$ & $\begin{array}{c}\text { Mean } \\
\text { difference }\end{array}$ & $P$ \\
\hline \multirow[t]{6}{*}{$\mathrm{PI}$} & $\begin{array}{l}\text { Group } 1 \text { (GCP) versus } \\
\text { Group } 2 \text { (GCP-DM) }\end{array}$ & -0.20 & 0.24 \\
\hline & $\begin{array}{l}\text { Group } 1 \text { (GCP) versus } \\
\text { Group } 3 \text { (DM) }\end{array}$ & -0.23 & 0.16 \\
\hline & $\begin{array}{l}\text { Group } 1(\mathrm{GCP}) \text { versus } \\
\text { Group } 4(\mathrm{PH})\end{array}$ & 0.92 & $0.001^{* *}$ \\
\hline & $\begin{array}{l}\text { Group } 2 \text { (GCP-DM) } \\
\text { versus Group } 3 \text { (DM) }\end{array}$ & -0.02 & 0.99 \\
\hline & $\begin{array}{l}\text { Group } 2 \text { (GCP-DM) } \\
\text { versus Group } 4(\mathrm{PH})\end{array}$ & 1.12 & $0.001^{* *}$ \\
\hline & $\begin{array}{l}\text { Group } 3(\mathrm{DM}) \text { versus } \\
\text { Group } 4(\mathrm{PH})\end{array}$ & 1.15 & $0.001^{* *}$ \\
\hline \multirow[t]{6}{*}{ GI } & $\begin{array}{l}\text { Group } 1 \text { (GCP) versus } \\
\text { Group } 2 \text { (GCP-DM) }\end{array}$ & -0.24 & 0.07 \\
\hline & $\begin{array}{l}\text { Group } 1 \text { (GCP) versus } \\
\text { Group } 3 \text { (DM) }\end{array}$ & 0.12 & 0.61 \\
\hline & $\begin{array}{l}\text { Group } 1(\mathrm{GCP}) \text { versus } \\
\text { Group } 4(\mathrm{PH})\end{array}$ & 1.37 & $0.001^{* *}$ \\
\hline & $\begin{array}{l}\text { Group } 2 \text { (GCP-DM) } \\
\text { versus Group } 3 \text { (DM) }\end{array}$ & 0.37 & $0.002^{* *}$ \\
\hline & $\begin{array}{l}\text { Group } 2 \text { (GCP-DM) } \\
\text { versus Group } 4(\mathrm{PH})\end{array}$ & 1.62 & $0.001^{* *}$ \\
\hline & $\begin{array}{l}\text { Group } 3(\mathrm{DM}) \text { versus } \\
\text { Group } 4(\mathrm{PH})\end{array}$ & 1.25 & $0.001^{* *}$ \\
\hline \multirow[t]{6}{*}{ PPD (mm) } & $\begin{array}{l}\text { Group } 1 \text { (GCP) versus } \\
\text { Group } 2 \text { (GCP-DM) }\end{array}$ & -0.13 & 0.30 \\
\hline & $\begin{array}{l}\text { Group } 1 \text { (GCP) versus } \\
\text { Group } 3 \text { (DM) }\end{array}$ & 2.97 & $0.001^{* *}$ \\
\hline & $\begin{array}{l}\text { Group } 1(\mathrm{GCP}) \text { versus } \\
\text { Group } 4(\mathrm{PH})\end{array}$ & 3.76 & $0.001^{* *}$ \\
\hline & $\begin{array}{l}\text { Group } 2 \text { (GCP-DM) } \\
\text { versus Group } 3 \text { (DM) }\end{array}$ & 3.11 & $0.001^{* *}$ \\
\hline & $\begin{array}{l}\text { Group } 2 \text { (GCP-DM) } \\
\text { versus Group } 4(\mathrm{PH})\end{array}$ & 3.90 & $0.001^{* \star}$ \\
\hline & $\begin{array}{l}\text { Group } 3(\mathrm{DM}) \text { versus } \\
\text { Group } 4(\mathrm{PH})\end{array}$ & 0.78 & $0.001^{* *}$ \\
\hline \multirow[t]{6}{*}{$\mathrm{CAL}(\mathrm{mm})$} & $\begin{array}{l}\text { Group } 1 \text { (GCP) versus } \\
\text { Group } 2 \text { (GCP-DM) }\end{array}$ & -0.35 & $0.034^{*}$ \\
\hline & $\begin{array}{l}\text { Group } 1 \text { (GCP) versus } \\
\text { Group } 3 \text { (DM) }\end{array}$ & 2.51 & $0.001^{* *}$ \\
\hline & $\begin{array}{l}\text { Group } 1(\mathrm{GCP}) \text { versus } \\
\text { Group } 4(\mathrm{PH})\end{array}$ & 2.51 & $0.001^{* *}$ \\
\hline & $\begin{array}{l}\text { Group } 2 \text { (GCP-DM) } \\
\text { versus Group } 3 \text { (DM) }\end{array}$ & 2.87 & $0.001^{* *}$ \\
\hline & $\begin{array}{l}\text { Group } 2 \text { (GCP-DM) } \\
\text { versus Group } 4(\mathrm{PH})\end{array}$ & 2.87 & $0.001^{* *}$ \\
\hline & $\begin{array}{l}\text { Group } 3(\mathrm{DM}) \text { versus } \\
\text { Group } 4(\mathrm{PH})\end{array}$ & 0.00 & 1.000 \\
\hline
\end{tabular}

${ }^{* *} P<0.01$, highly significant, ${ }^{*} P<0.05$, statistically significant. GCP: Generalized chronic periodontitis, GCP-DM: Generalized chronic periodontitis with DM, DM: Type II diabetes mellitus, PH: Periodontally healthy, CAL: Clinical attachment level, PPD: Probing pocket depth, Gl: Gingival index, PI: Plaque index

with evaluation of OSI in CP patients with type II DM. Hence, the present research was carried out to estimate the above biochemical parameters and correlate with the clinical parameters to determine

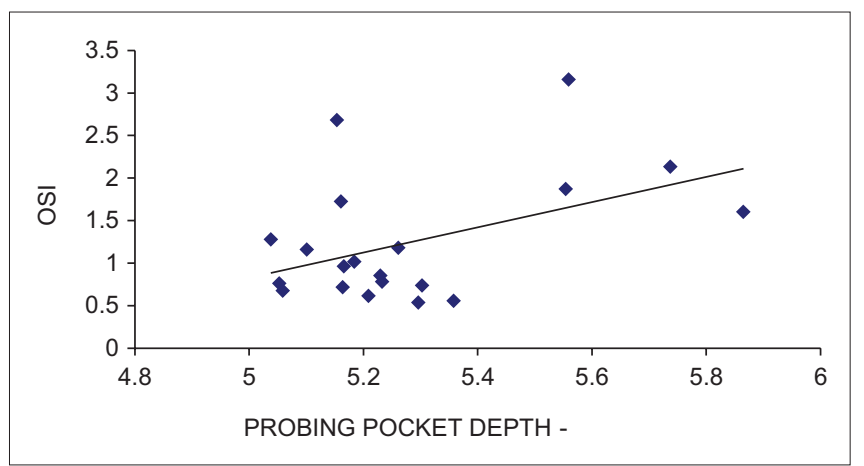

Figure 3: Correlation between probing pocket depth and oxidative stress index in Group 1 (chronic periodontitis without diabetes mellitus)

the effect of OS in participants with both coexisting $\mathrm{CP}$ and type II DM.

It was observed that GCF TAOC was significantly lower in participants with CP, DM and with both the disease conditions when compared to systemically and PH controls $(P<0.01)$. This finding was in agreement with the previous studies. ${ }^{[18,19,22,23]}$ A tabay et al. in their study revealed that GCF TAOC were significantly lower in normal weight $\mathrm{CP}$ patients when compared with normal weight healthy participants $(P<0.01) \cdot{ }^{[19]}$ Akalin et al., ${ }^{[22]}$ Canakci et al. ${ }^{[23]}$ and Baltacioğlu et al. ${ }^{[24]}$ revealed that GCF and serum TAOC were significantly lower in pregnant, preeclamptic and postmenopausal women with $\mathrm{CP}$, respectively.

As evidenced by the multitude of studies, ${ }^{[3,4,10,11]}$ it is well known that periodontitis induces a low-grade inflammation, thereby creating an oxidative environment with reduced antioxidant capacity. Periodontal pathogens activate host response leading to the activation of neutrophils and macrophages, the primary sources of free radicals in periodontitis. The primed neutrophils bind to bacteria either directly or indirectly by cell surface receptors and $\mathrm{FcV}$ receptors initiating phagocytosis. This process is associated with powerful oxidative burst causing excessive release of oxygen free radicals leading to the subsequent killing of the microorganisms. Inadvertently, there is associated extracellular release of these reactive species that contribute to tissue damage. ${ }^{[5,9-11]}$ Decreased TAOC levels observed in periodontitis participants could be attributed to depletion of antioxidants to constantly neutralize the exaggerated ROS activity during periodontal inflammation.

It was observed that among all the four groups, GCF TAOC was lowest in patients with CP-DM (Group 2). This could be attributed to hyperglycemia the 


\begin{tabular}{|c|c|c|c|c|c|}
\hline \multirow[t]{2}{*}{ Parameters } & \multicolumn{4}{|c|}{ Mean \pm SD } & \multirow[t]{2}{*}{$P$} \\
\hline & $\begin{array}{c}\text { Group } 1 \\
\text { (GCP) }\end{array}$ & $\begin{array}{c}\text { Group } 2 \\
\text { (GCP-DM) }\end{array}$ & $\begin{array}{l}\text { Group } 3 \\
\text { (DM) }\end{array}$ & $\begin{array}{c}\text { Group } 4 \\
\text { (PH) }\end{array}$ & \\
\hline $\begin{array}{l}\text { TAOC } \\
(\mathrm{mmol} / \mathrm{L})\end{array}$ & $0.75 \pm 0.24$ & $0.69 \pm 0.19$ & $0.77 \pm 0.27$ & $1.20 \pm 0.41$ & $0.001^{* *}$ \\
\hline $\begin{array}{l}\text { TOS } \\
(\mu \mathrm{mol} / \mathrm{L})\end{array}$ & $9.08 \pm 3.70$ & $10.05 \pm 3.26$ & $7.84 \pm 1.50$ & $5.20 \pm 1.30$ & $0.001^{* *}$ \\
\hline OSI & $1.24 \pm 0.73$ & $1.39 \pm 0.62$ & $1.00 \pm 0.52$ & $0.52 \pm 0.36$ & $0.001^{* *}$ \\
\hline
\end{tabular}

\begin{tabular}{|c|c|c|c|}
\hline $\begin{array}{l}\text { Biochemical } \\
\text { parameter at } \\
\text { baseline }\end{array}$ & $\begin{array}{l}\text { Pairwise comparison } \\
\text { between groups }\end{array}$ & $\begin{array}{c}\text { Mean } \\
\text { difference }\end{array}$ & $P$ \\
\hline \multirow[t]{6}{*}{ TAOC (mmol/L) } & $\begin{array}{l}\text { Group } 1 \text { (GCP) versus } \\
\text { Group } 2 \text { (GCP-DM) }\end{array}$ & 0.057 & 0.92 \\
\hline & $\begin{array}{l}\text { Group } 1 \text { (GCP) versus } \\
\text { Group } 3(\mathrm{DM})\end{array}$ & -0.021 & 0.99 \\
\hline & $\begin{array}{l}\text { Group } 1(\mathrm{GCP}) \text { versus } \\
\text { Group } 4(\mathrm{PH})\end{array}$ & -0.44 & $0.001^{* *}$ \\
\hline & $\begin{array}{l}\text { Group } 2 \text { (GCP-DM) } \\
\text { versus Group } 3 \text { (DM) }\end{array}$ & -0.07 & 0.83 \\
\hline & $\begin{array}{l}\text { Group } 2 \text { (GCP-DM) } \\
\text { versus Group } 4(\mathrm{PH})\end{array}$ & -0.50 & $0.001^{* *}$ \\
\hline & $\begin{array}{l}\text { Group } 3(\mathrm{DM}) \text { versus } \\
\text { Group } 5(\mathrm{PH})\end{array}$ & -0.42 & $0.001^{* *}$ \\
\hline \multirow[t]{6}{*}{$\mathrm{TOS}(\mu \mathrm{mol} / \mathrm{L})$} & $\begin{array}{l}\text { Group } 1 \text { (GCP) versus } \\
\text { Group } 2 \text { (GCP-DM) }\end{array}$ & -0.96 & 0.66 \\
\hline & $\begin{array}{l}\text { Group } 1(\mathrm{GCP}) \text { versus } \\
\text { Group } 3 \text { (DM) }\end{array}$ & 1.23 & 0.45 \\
\hline & $\begin{array}{l}\text { Group } 1(\mathrm{GCP}) \text { versus } \\
\text { Group } 4(\mathrm{PH})\end{array}$ & 3.88 & $0.001^{* *}$ \\
\hline & $\begin{array}{l}\text { Group } 2 \text { (GCP-DM) } \\
\text { versus Group } 3 \text { (DM) }\end{array}$ & 2.20 & 0.05 \\
\hline & $\begin{array}{l}\text { Group } 2 \text { (GCP-DM) } \\
\text { versus Group } 4(\mathrm{PH})\end{array}$ & 4.85 & $0.001^{* *}$ \\
\hline & $\begin{array}{l}\text { Group } 3(\mathrm{DM}) \text { versus } \\
\text { Group } 4(\mathrm{PH})\end{array}$ & 2.64 & $0.012^{*}$ \\
\hline \multirow[t]{6}{*}{ OSI } & $\begin{array}{l}\text { Group } 1 \text { (GCP) versus } \\
\text { Group } 2 \text { (GCP-DM) }\end{array}$ & -0.14 & 0.86 \\
\hline & $\begin{array}{l}\text { Group } 1(\mathrm{GCP}) \text { versus } \\
\text { Group } 3 \text { (DM) }\end{array}$ & 0.24 & 0.54 \\
\hline & $\begin{array}{l}\text { Group } 1(\mathrm{GCP}) \text { versus } \\
\text { Group } 4(\mathrm{PH})\end{array}$ & 0.72 & $0.001^{* *}$ \\
\hline & $\begin{array}{l}\text { Group } 2 \text { (GCP-DM) } \\
\text { versus Group } 3 \text { (DM) }\end{array}$ & 0.38 & 0.15 \\
\hline & $\begin{array}{l}\text { Group } 2 \text { (GCP-DM) } \\
\text { versus Group } 4(\mathrm{PH})\end{array}$ & 0.86 & $0.001^{* *}$ \\
\hline & $\begin{array}{l}\text { Group } 3(\mathrm{DM}) \text { versus } \\
\text { Group } 4(\mathrm{PH})\end{array}$ & 0.47 & 0.05 \\
\hline $\begin{array}{l}{ }^{*} P<0.05 \text {, statistica } \\
\text { TAOC: Total antiox } \\
\text { OSI: Oxidative Str } \\
\text { periodontitis, GCP } \\
\text { DM, DM: Type II d }\end{array}$ & $\begin{array}{l}\text { nificant, }{ }^{*} P<0.01 \text {, highly } \\
\text { capacity, TOS: Total oxid } \\
\text { dex, GCP: Generalized } C \\
\text { Generalized chronic perio } \\
\text { s mellitus, PH: Periodont }\end{array}$ & $\begin{array}{l}\text { cant. } \\
\text { tus, } \\
\text { is with } \\
\text { althy }\end{array}$ & \\
\hline
\end{tabular}

primary cause of inflammation in diabetics and is also believed to increase inflammation in periodontal tissues. Excessive glucose levels induce free radical production and enhance OS by increased formation of AGEs, dysfunction of mitochondrial electron transport chain and protein kinase C-dependent activation of NADPH oxidase. ${ }^{[6-8]}$ These pathologic mechanisms in diabetes together with the preexisting periodontal disease could possibly be responsible for exacerbated periodontal destruction seen in diabetics, and also may explain the greater risk for periodontitis in diabetics. Thus, the coexistence of both the disease conditions further reduced the antioxidant capacity.

Wei et al., ${ }^{[25]}$ Panjamurthy et al., ${ }^{[26]}$ and Su et al. ${ }^{[27]}$ reported higher serum, salivary and GCF enzymatic antioxidant, superoxide dismutase activity, and TAOC in CP participants this was in contrast to the present study. These authors attributed their findings to an upregulated antioxidant enzyme system in cells and tissues as local response to increase in OS associated with periodontal inflammation.

In the present study, GCF TAOC levels negatively correlated with GI at baseline in Group $1(r=-0.481$; $P<0.05)$. This is possibly attributed to the reduced antioxidant levels with increased inflammatory burden in gingival tissues in periodontitis. Previous studies by Baltacioğlu et al., ${ }^{[24]}$ Atabay et al., ${ }^{[19]}$ and Akpinar et al. ${ }^{[28]}$ have also shown a similar relationship.

Analysis of GCF TOS in the current study showed significantly higher levels in participants with $\mathrm{CP}$, CP-DM, and DM when compared to the periodontally and systemically healthy group. Further, highest TOS were seen in CP-DM (Group 2) participants. When comparing the baseline GCF TOS and TAOC levels in the present study, the imbalance in oxidant and antioxidant status is clearly evident with the balance tipping in favor of elevated oxidants probably related to increased OS implicated in both the disease processes. OSI values were significantly higher in Group 1, 2, and 3 than PH controls $(P<0.01)$. This is probably due to increased oxidant status in both periodontal disease and DM. The present study results were supported by Wei et al. ${ }^{[25]}$ and Akalin et al. ${ }^{[29]}$ Both the authors reported elevated levels of serum, saliva and GCF TOS in CP patients and ascribed their findings to increased OS-induced both locally and systemically by periodontal disease. However, Zhang et al..$^{[30]}$ showed no such difference in the salivary TOS levels between $\mathrm{CP}$ and healthy controls. 


\section{CONCLUSIONS}

The study further validates the use of OSI as a marker for periodontal disease activity and role of OS in the pathogenesis of Type II diabetic patients with periodontal disease. Therefore, patients with diabetes need to be informed of their risk of periodontitis and periodontal therapy should be considered in the treatment of these patients.

\section{Financial support and sponsorship \\ Nil.}

\section{Conflicts of interest}

There are no conflicts of interest.

\section{REFERENCES}

1. Hajishengallis G, Lamont RJ. Beyond the red complex and into more complexity: The polymicrobial synergy and dysbiosis (PSD) model of periodontal disease etiology. Mol Oral Microbiol 2012;27:409-19.

2. Moore WE, Moore LV. The bacteria of periodontal diseases. Periodontol 2000 1994;5:66-77.

3. Kinane DF, Lappin DF. Immune processes in periodontal disease: A review. Ann Periodontol 2002;7:62-71.

4. Waddington RJ, Moseley R, Embery G. Reactive oxygen species: A potential role in the pathogenesis of periodontal diseases. Oral Dis 2000;6:138-51.

5. Cekici A, Kantarci A, Hasturk H, Van Dyke TE. Inflammatory and immune pathways in the pathogenesis of periodontal disease. Periodontol 2000 2014;64:57-80.

6. Taylor GW. Bidirectional interrelationships between diabetes and periodontal diseases: An epidemiologic perspective. Ann Periodontol 2001;6:99-112.

7. Mealey BL, Oates TW; American Academy of Periodontology. Diabetes mellitus and periodontal diseases. J Periodontol 2006;77:1289-303.

8. Nishimura F, Iwamoto Y, Mineshiba J, Shimizu A, Soga Y, Murayama $Y$, et al. Periodontal disease and diabetes mellitus: The role of tumor necrosis factor-alpha in a 2-way relationship. J Periodontol 2003;74:97-102.

9. Sies H. Oxidative stress: Oxidants and antioxidants. Exp Physiol 1997:82:291-9.

10. Chapple IL, Matthews JB. The role of reactive oxygen and antioxidant species in periodontal tissue destruction. Periodontol 2000 2007;43:160-232.

11. Halliwell B. Antioxidant defence mechanisms: From the beginning to the end (of the beginning). Free Radic Res 1999;31:261-72.

12. Esen C, Alkan BA, Kırnap M, Akgül O, Işıkoğlu S, Erel O, et al. The effects of chronic periodontitis and rheumatoid arthritis on serum and gingival crevicular fluid total antioxidant/oxidant status and oxidative stress index. J Periodontol 2012;83:773-9.

13. Baltacıŏlu E, Yuva P, Aydın G, Alver A, Kahraman C, Karabulut E, et al. Lipid peroxidation levels and total oxidant/antioxidant status in serum and saliva from patients with chronic and aggressive periodontitis. Oxidative stress index: A new biomarker for periodontal disease? J Periodontol 2014;85:1432-41.

14. Erel O. A novel automated method to measure total antioxidant response against potent free radical reactions. Clin Biochem 2004;37:112-9.

15. Erel O. A new automated colorimetric method for measuring total oxidant status. Clin Biochem 2005;38:1103-11.

16. Armitage GC. Periodontal diagnoses and classification of periodontal diseases. Periodontol 2000 2004;34:9-21.

17. American Diabetes Association. Diagnosis and classification of diabetes mellitus. Diabetes Care 2010;33 Suppl 1:S62.

18. Brock GR, Butterworth CJ, Matthews JB, Chapple IL. Local and systemic total antioxidant capacity in periodontitis and health. J Clin Periodontol 2004:31:515-21.

19. Atabay VE, Lutfioğlu M, Avci B, Sakallioglu EE, Aydoğdu A. Obesity and oxidative stress in patients with different periodontal status A case-control study. J Periodontal Res 2017;52:51-60.

20. Reuter S, Gupta SC, Chaturvedi MM, Aggarwal BB. Oxidative stress, inflammation, and cancer: How are they linked? Free Radic Biol Med 2010;49:1603-16.

21. Khansari N, Shakiba Y, Mahmoudi M. Chronic inflammation and oxidative stress as a major cause of age-related diseases and cancer. Recent Pat Inflamm Allergy Drug Discov 2009;3:73-80.

22. Akalin FA, Baltacioğlu E, Alver A, Karabulut E. Total antioxidant capacity and superoxide dismutase activity levels in serum and gingival crevicular fluid in pregnant women with chronic periodontitis. J Periodontol 2009;80:457-67.

23. Canakci V, Yildirim A, Canakci CF, Eltas A, Cicek Y, Canakci H, et al. Total antioxidant capacity and antioxidant enzymes in serum, saliva, and gingival crevicular fluid of preeclamptic women with and without periodontal disease. J Periodontol 2007;78:1602-11.

24. Baltacioğlu E, Akalin FA, Alver A, Balaban F, Unsal M, Karabulut E, et al. Total antioxidant capacity and superoxide dismutase activity levels in serum and gingival crevicular fluid in post-menopausal women with chronic periodontitis. J Clin Periodontol 2006;33:385-92.

25. Wei D, Zhang XL, Wang YZ, Yang CX, Chen G. Lipid peroxidation levels, total oxidant status and superoxide dismutase in serum, saliva and gingival crevicular fluid in chronic periodontitis patients before and after periodontal therapy. Aust Dent J 2010;55:70-8.

26. Panjamurthy K, Manoharan S, Ramachandran CR. Lipid peroxidation and antioxidant status in patients with periodontitis. Cell Mol Biol Lett 2005;10:255-64.

27. Su H, Gornitsky M, Velly AM, Yu H, Benarroch M, Schipper HM, et al. Salivary DNA, lipid, and protein oxidation in nonsmokers with periodontal disease. Free Radic Biol Med 2009;46:914-21.

28. Akpinar A, Toker H, Ozdemir H, Bostanci V, Aydin H. The effects of non-surgical periodontal therapy on oxidant and anti-oxidant status in smokers with chronic periodontitis. Arch Oral Biol 2013;58:717-23.

29. Akalin FA, Baltacioğlu E, Alver A, Karabulut E. Lipid peroxidation levels and total oxidant status in serum, saliva and gingival crevicular fluid in patients with chronic periodontitis. J Clin Periodontol 2007;34:558-65.

30. Zhang T, Andrukhov O, Haririan H, Müller-Kern M, Liu S, Liu Z, et al. Total antioxidant capacity and total oxidant status in saliva of periodontitis patients in relation to bacterial load. Front Cell Infect Microbiol 2015;5:97. 